\title{
PERBANDINGAN RETENSI SISWA SMP PADA PEMBELAJARAN IPA TERPADU KONSEP CAHAYA ANTARA MODEL PEMBELAJARAN BERBASIS MASALAH DAN METODE PEMBELAJARAN INKUIRI
}

\author{
COMPARISON RETENTION OF JUNIOR HIGH SCHOOL STUDENTS IN \\ INTEGRATED SCIENCE LEARNING BETWEEN PROBLEM-BASED LEARNING \\ AND INQUIRY LEARNING
}

\author{
Nina Yarana Silmiati \\ Dosen IPA Institut Agama Islam Latifah Mubarokiyah Tasikmalaya \\ E-mail: ninayarana@gmail.com
}

\begin{abstract}
ABSTRAK
Tujuan penelitian ini adalah melihat perbandingan retensi siswa SMP pada pembelajaran IPA terpadu antara model pembelajaran berbasis masalah dan metode pembelajaran inkuiri. Subjek penelitian adalah siswa kelas VIII SMP Negeri di Kota Bandung. Penelitian ini menggunakan metode quasi eksperimen dengan desain the static group pretest-posttetst design. Data dikumpulkan dengan menggunakan tes kemampuan kognitif dan tes retensi. Hasil penelitian menunjukkan bahwa model pembelajaran berbasis masalah dan metode pembelajaran inkuiri dapat meningkatkan kemampuan kognitif dengan baik dengan n-gain 0,54 dan 0,53 (kategori sedang) dan kedua pembelajaran tidak berbeda secara signifikan dengan nilai 0,871 ( $t$-test $>0,05$ ). Retensi siswa kedua kelas tidak berbeda secara signifikan dengan nilai 0,522 (t-test $>0,05)$ dan berada pada kategori sangat baik.

Kata kunci: pembelajaran IPA terpadu, model pembelajaran berbasis masalah, metode pembelajaran inkuiri, retensi.

\section{ABSTRACT}

The purpose of this research was to find out the retention level of junior high school students in integrated science learning who were taught using Problem-Based Learning and Inquiry Learning. The subjects of this research were all of grade VIII junior high school students in Bandung City. This research used a quasi-experimental design with the static group pretest-posttest design. The data was collected using of student's cognitive abilities and retention test. The results showed Problem-Based Learning and Inquiry Learning could positively improve student's cognitive abilities. The n-gain for both were 0.54 and 0.53 (medium category) respectively. Both of them did not differ significantly. It was proved by its score 0,871 (t-test $>0,05)$. Students' retention levels were not significantly different either since it was shown that the score was 0,522 (t-test $>0,05)$, which meant that both of them were considered to be in very good category.
\end{abstract}

Keyword: integrated science learning, problem based learning, inquiry learning, retention

\section{PENDAHULUAN}

Pendidikan merupakan pembelajaran pengetahuan, keterampilan, dan kebiasaan sekelompok manusia yang ditransfer dari satu generasi ke generasi berikutnya melalui pembelajaran, pelatihan, atau penelitian. Salah satu komponen pendidikan adalah pembelajaran di sekolah. Pembelajaran di sekolah dilakukan untuk mengembangkan minat dan bakat yang dimiliki siswa. Belajar merupakan suatu proses usaha yang dilakukan seseorang untuk memperoleh perubahan tingkah laku yang baru secara keseluruhan, sebagai hasil pengalamannya sendiri dalam interaksi dengan lingkungannya (Slameto, 2015:2).
Ilmu Pengetahuan Alam (IPA) merupakan suatu kumpulan pengetahuan yang tersusun secara sistematis, dan dalam penggunaannya secara umum terbatas pada gejala-gejala alam. Hakikat IPA sebagai produk, proses, aplikasi dan sikap harus selalu dilatihkan kepada siswa agar mereka memiliki bekal yang cukup dalam hal pengetahuan konsep dan keterampilan untuk melanjutkan ke jenjang lebih tinggi. Berdasarkan kurikulum 2013, Ilmu pengetahuan alam (IPA) pada tingkat SMP/MTs memfasilitasi pembelajaran yang selaras dengan hakikat IPA (Purwanti, 2013).

Kurikulum 2013 merupakan pengembangan dari Kurikulum Berbasis Kompetensi (KBK) 2004 dan Kurikulum 
Tingkat Satuan Pendidikan (KTSP) 2006. Ilmu Pengetahuan Alam (IPA) dalam kurikulum 2013 dibelajarkan dalam bentuk keterpaduan, baik keterpaduan konsep, keterpaduan sikap, keterpaduan keterampilan, maupun keterpaduan antara konsep, sikap, dan keterampilan. Sehingga, IPA pada tingkat SMP/MTs tidak disajikan secara disiplin keilmuan yang terpisah seperti : IPA Fisika, IPA Kimia, atau IPA Biologi. Akan tetapi, IPA merupakan satu kesatuan utuh yang terintegrasi satu sama lain. Hal ini sejalan dengan yang dikatakan oleh balitbang Depdiknas (2006:7) bahwa pembelajaran IPA yang disajikan secara disiplin keilmuan dianggap terlalu dini bagi anak usia 7-14. Anak usia 7-14 (usia SMP) masih dalam tahap transisi dari tingkat berpikir operasional konkret ke berpikir abstrak, selain itu usia ini masih melihat dunia sekitarnya secara holistik (menyeluruh). Sehingga pembelajaran IPA pada kurikulum 2013 yang dilaksanakan secara terpadu sesuai dengan tingkat kemampuan berpikir siswa (Madiniah, 2015).

Keterpaduan pembelajaran IPA yang diatur dalam kurikulum 2013 sangat membantu untuk mengefektifkan pembelajaran IPA di dalam kelas. Pembelajaran yang dilakukan secara parsial memungkinkan adanya tumpang tindih dan pengulangan yang membutuhkan waktu dan energi lebih banyak, serta membosankan bagi siswa. Sehingga, apabila konsep yang mengalami tumpang tindih ini dipadukan maka akan menjadikan pembelajaran lebih efektif dan efisien. Salah satu contoh dari tumpang tindih konsep adalah konsep mata. Pada displin ilmu biologi konsep ini dibahas sebagai alat indera yang membahas lebih lanjut tentang penglihatan manusia, dan lain-lain. Sedangkan pada disiplin ilmu fisika konsep mata juga dibahas sendiri sebagai alat optik yang membahas lebih lanjut tentang lensa mata, pembentukan bayangan pada mata, cacat mata, dan lainlain. Kesamaan konsep dalam dua disiplin ilmu ini dapat dibelajarkan secara bersamaan melalui pembelajaran IPA terpadu (Novrizal, 2012).

Fogarty dalam Duch, Groh, \& Allen (2014) menyebutkan terdapat 10 bentuk model keterpaduan pembelajaran, yaitu : (1) terpisah (Fragmented); (2) keterkaitan / Keterhubungan (Connected); (3) berbentuk Sarang/kumpulan (Nested); (4) satu rangkaian (Sequence); (5) terbagi (Shared); (6) jaring laba-laba (Webbed); (7) satu alur (Threaded); (8) integrasi (Integrated); (9) terbenam (Immersed); (10) jejaring (Networked). Dalam kurikulum 2013, model keterpaduan pembelajaran yang disarankan untuk digunakan adalah model keterpaduan integrated, shared, connected, dan webbed. Pemilihan model keterpaduan yang digunakan dalam kelas harus disesuaikan dengan pembelajaran yang akan dilaksanakan, karakteristik dari mata pelajaran, pendekatan keterpaduan yang dilakukan baik pendekatan kompetensi dasar maupun pendekatan topik/ tema.

Pembelajaran IPA terpadu dapat dikembangkan melalui tema, dimana tema dapat diambil dari isu-isu atau masalahmasalah yang berkembang saat ini di masyarakat. Pembelajaran IPA terpadu akan memberikan pemahaman yang lebih konkret dan holistik sehingga siswa dapat menerapkan hasil belajarnya dalam kehidupan sehari-hari. Berdasarkan kurikulum 2013, pembelajaran yang dilakukan harus dapat mengembangkan aspek pengetahuan, aspek sikap, aspek keterampilan, dan perpaduan dari beberapa aspek tersebut. Pemilihan aspek yang dikembangkan disesuaikan dengan kegiatan pembelajaran yang dilakukan dan juga materi yang akan diajarkan (Fransiska, 2016).

Hasil wawancara dengan guru IPA di salah satu Sekolah Menengah Pertama di kota Bandung diketahui bahwa sampai saat ini pembelajaran IPA masih dibelajarkan sebagai mata pelajaran yang terpisah (Biologi, Fisika, dan Kimia). Beberapa faktor yang mendasari guru belum melaksanakan IPA secara terpadu adalah: (1) masih rendahnya 
motivasi guru dalam mengajarkan IPA secara terpadu karena tidak sesuai dengan bidang keahliannya, (2) guru merasa kurang maksimal ketika harus mengajar bidang diluar keahliannya, (3) guru belum memiliki pemahaman tentang pengintegrasian konsepkonsep IPA, karena selama ini terbiasa mengajarkan IPA secara terpisah, (4) guru mengalami kesulitan karena belum adanya pelatihan tentang pembelajaran IPA terpadu secara meluas (Madiniah, 2015).

Hasil studi lapangan dan observasi pada pembelajaran IPA yang dilakukan menunjukkan ketercapaian kompetensi siswa baik kompetensi pengetahuan maupun kompetensi sikap yang masih rendah. Kompetensi pengetahuan yang rendah ditunjukkan dari rata-rata ulangan harian bab usaha dan energi yaitu 45 dengan nilai KKM 75 . Hanya 2 siswa $(6,1 \%)$ yang memperoleh nilai di atas KKM, 13 siswa memperoleh nilai antara $50 \mathrm{~s} / \mathrm{d} 74$ (39,4\%), dan 18 siswa memperoleh nilai di bawah $50(54,5 \%)$. Hasil ini menunjukkan bahwa hampir setengah lebih siswa belum mencapai kompetensi. Hal serupa juga ditunjukkan oleh nilai ulangan harian bab gaya yaitu dengan rata-rata yang diperoleh 53.

Berdasarkan beberapa fakta yang ditemukan di lapangan, pembelajaran IPA terpadu dapat menjadi salah satu solusinya. Pembelajaran secara terpadu diharapkan akan menghasilkan pembelajaran yang holistik, bermakna, autentik, dan aktif. Salah satu pembelajaran yang dapat memberikan pembelajaran yang holistik, bermakna, autentik, dan aktif adalah pembelajaran menggunakan metode pembelajaran inkuiri dan modelpembelajaran berbasis masalah. Metodepembelajaran inkuiri dapat mengajak siswa untuk menemukan sendiri konsep yang dipelajari dalam kelas, sehingga siswa akan lebih semangat mencari tau dan akhirnya akan lebih mengingat konsep tersebut dibandingkan pembelajaran biasa. Sedangkan model pembelajaran berbasis masalah menggunakan masalah yang kontekstual dalam kehidupan sehari-hari sebagai inti pembelajaran, sehingga pada pembelajaran ini siswa lebih antusias menemukan solusi untuk masalah yang di kemukakan dalam pembelajaran yang pada akhirnya siswa akan lebih mengingat konsep karena ada hubungannya dengan kehidupan sehari-hari mereka (Kirschner, Sweller, \& Clark, 2016; Hmelo-Silver, 2014).

Ausubel dalam Borko \& Putnam (2013:110) menyatakan bahwa belajar dapat diklasifikasikan kedalam dua dimensi. Dimensi pertama berkaitan dengan bagaimana cara informasi atau materi ajar tersebut disajikan pada siswa, apakah melalui penerimaan atau penemuan. Dimensi kedua menyangkut cara bagaimana siswa dapat menghubungkan informasi itu pada struktur kognitif yang telah ada. Pada dimensi kedua ini, "belajar bermakna" terjadi jika siswa dapat menghubungkan atau mengaitkan informasi itu pada pengetahuan (berupa konsep-konsep dan lain-lain) yang telah dimilikinya. Informasi yang diperoleh secara bermakna, biasanya akan lebih diingat dibandingkan dengan informasi yang diperoleh secara hafalan.

Siswa yang mengalami pembelajaran secara bermakna akan lebih mengingat materi pelajaran yang telah diajarkan di dalam kelas. Pembelajaran yang bermakna bagi siswa dapat lebih mempertahankan retensi yang dimiliki oleh siswa. Kurniawan (2016) menemukan bahwa pembelajaran bermakna melalui pembelajaran inkuiri terbimbing berbantuan cmaptools lebih dapat mempertahankan retensi siswa lebih baik dibandingkan pembelajaran secara konvensional yang biasa dilakukan di sekolah. Purwanti (2013) mengungkapkan bahwa (1) materi pelajaran yang bermakna akan lebih mudah diingat siswa dibandingkan dengan materi yang tidak bermakna, (2) Retensi akan lebih baik untuk materi yang bersifat kontekstual.

Metode pembelajaran berbasis inkuiri merupakan pembelajaran yang menekankan 
pada proses berpikir kritis dan analitis untuk mencari dan menemukan sendiri jawaban dari suatu masalah yang dipertanyakan (Sanjaya, 2014:196). Secara umum, Sanjaya (2012:201) mengungkapkan bahwa proses pembelajaran menggunakan pembelajaran inkuiri mengikuti langkah-langkah sebagai berikut: (1) Orientasi, (2) Merumuskan masalah, (3) Merumuskan hipotesis, (4) Mengumpulkan data, (5) Menguji hipotesis, dan (6) Merumuskan kesimpulan.

Pembelajaran berbasis masalah merupakan pembelajaran yang menyodorkan berbagai masalah autentik kepada siswa dan memerintah mereka untuk menyelidiki dan menemukan sendiri solusinya. Masalah yang dimunculkan merupakan masalah yang bersifat fakta, baik bersumber dari buku teks maupun sumber lain seperti internet, peristiwa yang terjadi di lingkungan sekitar, maupun fenomena alam. Hernani, Mudzakir, \& Aisyah (2015:57) mengungkapkan lima tahapan dalam pembelajaran berbasis masalah, yaitu: (1) memberikan orientasi kepada siswa tentang permasalahannya, (2) Mengorganisasikan siswa untuk meneliti, (3) Membantu investigasi mandiri dan kelompok, (4) Mengembangkan dan mempresentasikan artefak dan exhibit, (5) Menganalisis dan mengevaluasi pekerjaan.

Analisis yang dilakukan terhadap kompetensi inti dan kompetensi dasar IPA SMP/MTs pada kurikulum 2013, salah satu topik yang dapat diajarkan pada pembelajaran IPA terpadu adalah topik cahaya. Topik ini merupakan salah satu topik yang dapat dibahas pada kelas VIII di kurikulum 2013. Topik ini sangat erat kaitannya dengan kehidupan sehari-hari siswa. Dengan menggunakan topik cahaya, siswa akan belajar tentang konsep cahaya, konsep alat optik, konsep mata, dan lain-lain. Dari topik tersebut siswa dapat memperoleh pengetahuan yang utuh dan mendalam dari masing-masing disiplin ilmu yang terkait sehingga dapat mengaplikasikan hasil pembelajarannya dalam kehidupan sehari-hari. Oleh karena itu, penelitian ini akan melihat retensi siswa dari dua kelas eksperimen yang menggunakan pembelajaran IPA terpadu dengan model pembelajaran berbasis masalah dan metode inkuiri.

\section{METODE PENELITIAN}

Penelitian ini bertujuan untuk melihat retensi siswa setelah dilakukan pembelajaran. Penelitian termasuk eksperimen semu (quasi experiment). Desain penelitian adalah the static group pretest-posttetst designdengan menggunakan kelas eksperimen 1 (model pembelajaran berbasis masalah) dan eksperimen 2 (metode pembelajaran inkuiri). Populasi dalam penelitian adalah seluruh siswa kelas VIII salah satu SMP Negeri di Kota Bandung. Teknik pengambilan sampel dengan purposive sampling dengan kelas VIII C sebagai kelas eksperimen 1 dan kelas VIII D sebagai kelas eksperimen 2.

Pada penelitian terdapat dua variabel bebas yaitu model pembelajaran berbasis masalah dan metode pembelajaraninkuiri serta satu variabel terikat yaitu retensi. Teknik pengumpulan data yang digunakan dalam penelitian adalah tes. Tes yang digunakan adalah tes kemampuan kognitif untuk mengukur kemampuan kognitif siswa, dan retest untuk mengukur retensi siswa. Tes dilakukan sebanyak tiga kali yaitu postest, retest 1 dan retest 2 digunakan untuk mengukur retensi terdiri dari dua puluh lima soal. Retest 1 dilakukan empat hari setelah posttest dan Retest 2 dilakukan 10 hari setelah retest 1 . Cara mengukur retensi dengan rumus recognition method:

$$
R=\frac{\text { Retest }}{\text { Posttest }} \times 100 \%
$$

Berikut merupakan interprtesi kriteria dari perolehan skor retensi pada tabel 1 .

Validasi instrumen penelitian di uji dengan dengan uji validitas, reliabilitas, daya pembeda, dan tingkat kesukaran item soal. Validitas konstruk di uji kelayakannya oleh pendapat dari ahli (judgement experts). Selanjutnya instrumen diujicobakan 
Tabel 1

Kriteria retensi

\begin{tabular}{cc}
\hline Skor & Kriteria \\
\hline $\mathrm{R} \geq 80 \%$ & Sangat Baik \\
\hline $70 \%-79 \%$ & Baik \\
\hline $60 \%-69 \%$ & Cukup \\
\hline $50 \%-59 \%$ & Kurang \\
\hline$\leq 49 \%$ & Sangat Kurang \\
\hline
\end{tabular}

(Syah, 2010)

kemudian validitas butir soal dihitung dengan perhitungan rumus koefisien korelasiproduct moment. Uji reliabilitas menggunakan uji Spearman-Brown. Validitas, reliabilitas, daya pembeda, dan tingkat kesukaran item soal dihitung dengan bantuan software Anates V4 dengan reliabilitas tes sebesar 0.70. Hal ini berarti bahwa reliabilitas soal sangat tinggi. Teknik analisis data terdiri dari uji prasyarat dan uji hipotesis. Uji prasyarat meliputi uji normalitas dan uji homogenitas. Uji normalitas menggunakan uji Kolmogorof Smirnof dan uji homogenitas menggunakan uji Levene's. Sedangkan uji hipotesis menggunakan uji t. Semua uji dibantu program SPSS 16.

\section{HASIL DAN PEMBAHASAN}

Data penelitian berupa nilai retensi siswa. Data dianalisis dengan uji t untuk mengetahui perbedaanretensi antara model pembelajaran berbasis masalah dan metode pembelajaran inkuiri.Hasil analisis statistik perbedaan retensi siswa antara pembelajaran berbasis masalah dan pembelajaran inkuiri disajikan pada tabel 2 .

Tabel 2

Hasil uji hipotesis retensi siswa antara Pembelajaran berbasis masalah dan pembelajaran inkuiri

\begin{tabular}{|c|c|c|c|c|c|c|c|c|c|c|c|c|}
\hline \multirow[b]{2}{*}{ Nilai } & \multicolumn{6}{|c|}{ Kelas Eksperimen 1} & \multicolumn{6}{|c|}{ Kelas Eksperimen 2} \\
\hline & $\begin{array}{l}\text { Pre- } \\
\text { test }\end{array}$ & $\begin{array}{c}\text { Post- } \\
\text { test } \\
\text { ke-1 }\end{array}$ & $\begin{array}{c}\text { Post- } \\
\text { test } \\
\text { ke-2 }\end{array}$ & $\begin{array}{c}\text { Post- } \\
\text { test } \\
\text { ke-3 }\end{array}$ & $\begin{array}{c}\text { Retensi } \\
\text { ke-1 }\end{array}$ & $\begin{array}{c}\text { Retensi } \\
\text { ke-2 }\end{array}$ & $\begin{array}{l}\text { Pre- } \\
\text { test }\end{array}$ & $\begin{array}{c}\text { Post- } \\
\text { test } \\
\text { ke-1 }\end{array}$ & $\begin{array}{c}\text { Post- } \\
\text { test } \\
\text { ke-2 }\end{array}$ & $\begin{array}{c}\text { Post- } \\
\text { test } \\
\text { ke-3 }\end{array}$ & $\begin{array}{c}\text { Retensi } \\
\text { ke-1 }\end{array}$ & $\begin{array}{c}\text { Retensi } \\
\text { ke-2 }\end{array}$ \\
\hline $\mathrm{R}$ & 8 & 12 & 13 & 13 & $80 \%$ & $70 \%$ & 6 & 10 & 10 & 12 & $77 \%$ & $72 \%$ \\
\hline $\mathrm{T}$ & 16 & 24 & 24 & 24 & $144 \%$ & $125 \%$ & 17 & 24 & 23 & 23 & $180 \%$ & $170 \%$ \\
\hline $\bar{x}$ & 12 & 18.20 & 19.60 & 19.03 & $108 \%$ & $97 \%$ & 11.37 & 16.31 & 19.83 & 19.57 & $122 \%$ & $99 \%$ \\
\hline
\end{tabular}

Berdasarkan data pada tabel di atas, dapat dilihat bahwa skor rata-rata pada posttest $1 \mathrm{ke}$ posttest 2 mengalami kenaikan untuk kedua kelas eksperimen. Sedangkan untuk rata-rata posttest 2 ke posttest 3 mengalami penurunan. Posttest 1 dilaksanakan pada tanggal $26 \mathrm{Mei}$ 2014 , posttest 2 dilaksanakan pada tanggal 30 Mei 2014, dan posttest 3 dilaksanakan pada tanggal 10 juni 2014. Retensi siswa pada pembelajaran IPA terpadu dengan model pembelajaran berbasis masalah diperoleh rata-rata retensi 1 sebesar $108 \%$ dan retensi 2 sebesar 97\%. Sedangkan retensi pada pembelajaran IPA terpadu dengan metode pembelajaran inkuiri diperoleh rata-rata retensi 1 sebesar $122 \%$ dan retensi 2 sebesar $99 \%$.

Untuk mengetahui apakah perbedaan skor rata-rata retensi siswa tersebut signifikan atau tidak, maka dilakukan uji signifikansi perbedaan rata-rata (uji hipotesis) untuk nilai retensi. Analisis dilakukan dengan terlebih dahulu menguji normalitas dan homogenitas terhadap data retensi, kemudian dilanjutkan dengan uji signifikansi perbedaan rata-rata. Berikut ini merupakan tabel rekapitulasi hasil uji normalitas dan homogenitas terhadap retensi yang dinormalisasi untuk kelas eksperimen 1 dan kelas eksperimen 2.

Dari Tabel 3 dapat disimpulkan bahwa 
Tabel 3

Rekapitulasi hasil uji normalitas, homogenitas, dan hipotesis data retensi kelas eksperimen 1 dan kelas eksperimen 2

\begin{tabular}{|c|c|c|c|c|c|c|c|}
\hline \multirow[b]{2}{*}{$N$-gain } & \multirow{2}{*}{$\begin{array}{c}\mathrm{N} \\
\text { (jumlah } \\
\text { siswa) }\end{array}$} & \multicolumn{2}{|r|}{ Uji Normalitas } & \multicolumn{2}{|c|}{ Uji Homogenitas } & \multicolumn{2}{|c|}{ Uji Hipotesis } \\
\hline & & Sig. & Interpretasi & Sig. & Interpretasi & Sig. & Interpretasi \\
\hline Kelas Eksperimen & 35 & 0,000 & $\begin{array}{c}\text { Distribusi Data Tidak } \\
\text { Normal }\end{array}$ & \multirow{2}{*}{0,345} & \multirow{2}{*}{$\begin{array}{c}\text { Varians } \\
\text { Data Homogen }\end{array}$} & \multirow{2}{*}{0,522} & \multirow{2}{*}{$\mathrm{H}_{0}$ diterima } \\
\hline Kelas Kontrol & 35 & 0,000 & $\begin{array}{c}\text { Distribusi Data Tidak } \\
\text { Normal }\end{array}$ & & & & \\
\hline
\end{tabular}

data retensi kelas eksperimen 1 dan kelas eksperimen 2 berdistribusi tidak normal dan homogen. Pada kelas eksperimen 1 pada distribusi data retensi siswa diperoleh signifikansi $0,000($ sig. $<0,050)$ dan pada kelas eksperimen 2 diperoleh signifikansi 0,000 (sig.<0,050). Berdasarkan hasil tersebut, dapat disimpulkan bahwa data retensi siswa pada kelas eksperimen 1 dan kelas eksperimen 2 berdistribusi tidak normal. Selain itu, pada perhitungan uji homogenitas menggunakan Levene Test (Test of Homogeneity of Variences) diperoleh nilai signifikansi data retensi siswa sebesar 0,345 (sig.>0,050), sehingga dapat disimpulkan bahwa varians kedua kelompok data adalah homogen. Oleh karena data berdistribusi tidak normal dan homogen, maka selanjutnya data diolah dengan statistik non-parametrik dengan uji Mann-Whitney.

Hasil uji hipotesis diperoleh taraf signifikansi sebesar 0,522. Nilai taraf signifikansi ini menunjukkan nilai yang lebih besar dari 0,05 yang berarti bahwa pada taraf kepercayaan 95\% retensi siswa pada model pembelajaran berbasis masalah tidak berbeda secara signifikan dibandingkan metode pembelajaran inkuiri. Dengan kata lain, dapat dikatakan bahwa kedua pembelajaran IPA terpadu yaitu dengan model pembelajaran berbasis masalah dan metode pembelajaran inkuiri dapat sama-sama memperoleh retensi siswa dalam kategori sangat baik.

Berdasarkan data pada tabel 2 dapat dilihat bahwa skor rata-rata pada posttest 1 ke posttest 2 mengalami kenaikan untuk kedua kelas eksperimen. Sedangkan untuk rata-rata posttest 2 ke posttest 3 mengalami penurunan. Hal ini dapat terjadi karena jarak antara posttest 1 dan posttest 2 yang terlalu dekat, hanya selang 4 hari. Dilihat dari penurunan skor rata-rata dari posttest $2 \mathrm{ke}$ posttest 3 terlihat bahwa penurunanya tidak terlalu besar baik pada kelas eksperimen 1 maupun pada kelas ekperimen 2. Hal ini sejalan dengan pernyataan I hear and I forget, I see and I remember, I do and I understand, bahwa dengan terlibat langsung dalam pembelajaran maka siswa akan memiliki pemahaman yang lebih dibandingkan dengan hanya mendengar saja. Perurunan retensi siswa dapat dilihat pada gambar 1 .

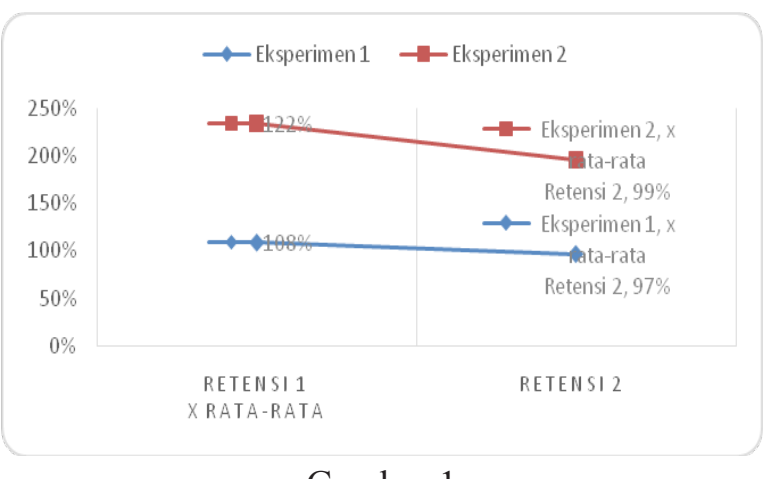

Gambar 1

Retensi siswa pada masing-masing kelas

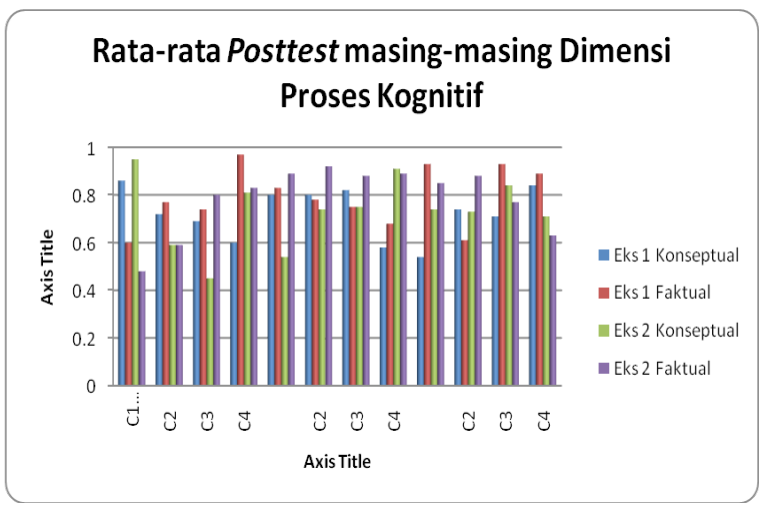

Gambar 2

Skor siswa pada kedua kelas eksperimen 
Berdasarkan gambar 1 dapat dilihat bahwa terjadi penurunan retensi siswa. Penurunan ini tidak terlalu besar, sehingga retensi siswa masih dalah kategori sangat baik. Berikut merupakan rata-rata posttest untuk masingmasing dimensi proses untuk kedua kelas eksperimen.

Retensi merupakan kemampuan menyimpan informasi atau konsep yang masuk pada memori jangka panjang siswa. Informasi yang telah diterima siswa kemudian mengalami pemrosesan informasi. Teori yang menjelaskan bagaimana informasi dapat diproses dengan baik adalah teori model pemrosesan informasi. Informasi diterima siswa melalui indera kemudian masuk ke dalam memori jangka pendek. Informasi dalam memori jangka pendek dapat dikode kemudian disimpan dalam memori jangka panjang. Pengodean (coding) merupakan proses transformasi yaitu informasi baru diintegrasi dengan informasi lama. Siswa mampu mengingat dengan baik atau retensi sangat baik apabila informasi yang berhasil dikode masuk ke dalam memori jangka panjang, saat informasi dipanggil kembali akan muncul dengan baik. Model pembelajaran berbasis masalah dan metode pembelajaran inkuiri merupakan pembelajaran yang berlandaskan pada perspektif konstruktivis, sehingga siswa terlibat aktif membangun konsep sendiri.

Proses membangun konsep sendiri oleh siswa melalui penerapan model pembelajaran berbasis masalah dan metode pembelajaran inkuiri melibatkan teknik pemrosesan informasi. Pemrosesan informasi terdiri dari tiga tahapan yaitu proses mencamkan (encoding), proses menyimpan (storage), dan proses pengingatan kembali (retrieval). Tahap encoding disebut sebagai tahap pengodean terhadap sesuatu yang akan diingat. Pengodean menghasilkan memori yang baik apabila dilakukan dengan mencari hubungan tentang sesuatu yang harus diingat dengan hal lain yang telah dikenal.

Menurut Gallagher, Stepien, \& Rosenthal
(2012), pengodean (coding) merupakan proses transformasi dimana informasi lama diintegrasikan dengan berbagai cara. Pada tahap coding informasi yang diterima siswa kemudian diproses dengan mengubah informasi tersebut ke dalam bentuk yang sesuai dengan sifat-sifat memori siswa. Siswa dengan perlakuan model pembelajaran berbasis masalah dan metode pembelajaran inkuiri lebih mudah melakukan coding karena siswa mencoba memecahkan dan mencari solusi masalah secara langsung, sehingga informasi dapat tersimpan dalam memori jangka panjang siswa. Informasi yang berada dalam jangka panjang dapat bertahan lama.

Retensi siswa meningkat apabila siswa dapat memanggil kembali informasi yang tersimpan dalam memori jangka panjang. Selain itu, model pembelajaran berbasis masalah dan metode pembelajaran inkuiri mampu menciptakan pembelajaran yang bermakna, sehingga siswa dapat memiliki retensi yang lebih baik. Informasi yang dipelajari secara bermakna mempermudah belajar hal-hal yang mirip walaupun telah terjadi lupa. Pernyataan ini sesuai dengan teori belajar Ausubel, bahwa belajar dikatakan bermakna (meaningful) jika informasi yang dipelajari siswa disusun sesuai dengan struktur kognitif yang dimiliki siswa, sehingga siswa dapat mengaitkan informasi baru yang diterima dengan struktur kognitif yang dimilikinya (Wong \& Day, 2014).

Tahapan pada model pembelajaran berbasis masalah dan metode pembelajaran inkuri membantu siswa dalam memahami informasi berupa konsep yang telah dipelajari sehingga materi yang telah dipelajari tertanam dalam memori jangka panjang. Fakta bahwa pembelajaran berbasis masalah berpengaruh terhadap retensi siswa sesuai dengan simpulan Schmidt dan Moust dalam Novianti \& Tjalla (2013), bahwa pembelajaran berbasis masalah berpengaruh pada retensi pengetahuan jangka panjang tentang mengingat kembali dan memahami beberapa konsep. Pendapat lain oleh Trianto 
(2012) bahwa ciri model pembelajaran berbasis masalah yaitu menghadapkan siswa pada masalah, sehingga siswa akan berusaha mencari solusi dari masalah tersebut dengan penyelidikan sehingga siswa lebih mengingat materi yang telah disampaikan dari pada sekedar menghafalnya.

Berdasarkan hasil penelitian dapat diketahui bahwa pembelajaran berbasis masalah mempunyai potensi untuk menguatkan retensi siswa. Hal ini didukung oleh pendapat Minner, Levy, \& Century (2016) bahwa pembelajaran berbasis masalah dapat membantu siswa lebih ingat. Salah satu kelebihan model pembelajaan berbasis masalah ini dapat membantu siswa untuk mencapai tujuan pembelajaran. Jika retensi siswa baik maka pembelajaran akan berjalan lancar. Pendapat lain oleh Kirschner et al. (2016) bahwa dengan penerapan model pembelajaran berbasis masalah hasil retensi siswa meningkat dibandingkan dengan pembelajaran tradisional.

Berdasarkan data yang diperoleh terbukti bahwa rata-rata retensi siswa ada kedua kelas eksperimen berada pada kategori sangat baik. Nilai rata-rata retensi 1 kelas eksperimen 1 sebesar $108 \%$ dan kelas eksperimen 2 sebesar $122 \%$. Nilai rata-rata retensi 2 kelas eksperimen 1 sebesar 97\% dan kelas eksperimen 2 sebesar 99\%. Hasil penelitian Gallagher et al. (2012) menunjukkan bahwa retensi siswa yang aktif berpartisipasi dalam mencari informasi lebih baik dari retensi siswa pada kelas dengan guru yang lebih aktif dalam pembelajaran. Berikut ini merupakan hasil retensi siswa untuk masing-masing konsep.

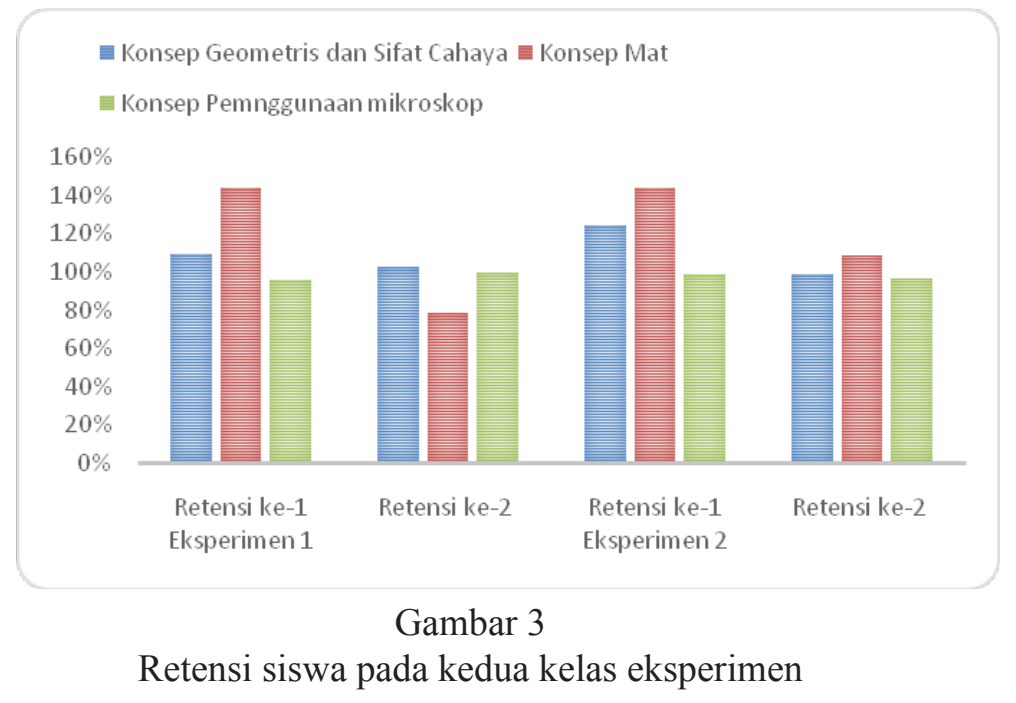

\section{SIMPULAN}

Tidak terdapat perbedaan retensi yang signifikan antara model pembelajaran berbasis masalah dan metode pembelajaran inkuiri pada pembelajaran IPA terpadu tema cahaya. Retensi siswa pada pembelajaran IPA terpadu dengan model pembelajaran berbasis masalah diperoleh rata-rata retensi 1 sebesar $108 \%$ dan retensi 2 sebesar 97\%. Sedangkan retensi pada pembelajaran IPA terpadu dengan metode pembelajaran inkuiri diperoleh ratarata retensi 1 sebesar $122 \%$ dan retensi 2 sebesar 99\%. Hal ini karena pembelajaran pada model pembelajaran berbasis masalah dan metode inkuiri menerapkan pemrosesan informasi sehingga siswa melakukan coding.

\section{REKOMENDASI}

Dalam meningkatkan retensi siswa dalam pembelajaran ipa terpadu, terlebih dalam konsep cahaya sebaiknya menggunakan medel pembelajaran lain. Karena terbukti dari penelitian ini bahwa model pembelajaran berbasis masalah dan model pembelajaran inkuiri tidak menghasilkan perbedaan retensi yang significant. Terlebih dengan banyaknya model pembelajaran lain yang dapat dilakukan untuk dapat meningkatkan retensi 
siswa.

\section{DAFTAR RUJUKAN}

Borko, H., \& Putnam, R. (2013). Learning to teach. USA: Bloomsbury. Retrieved from

Duch, B. J., Groh, S. E., \& Allen, D. E. (2014). The power of problem-based learning : a practical \&quot; how to\&quot; for teaching undergraduate courses in any discipline. USA: Stylus Pub.

Fransiska, K. (2016). Pengaruh Model Pembelajaran Inkuiri Disertai Media Lingkungan Terhadap Hasil Belajar Ipa-Fisika. Jurnal Pendidikan, 1(10), 90-98.

Gallagher, S. A., Stepien, W. J., \& Rosenthal, H. (2012). The Effects of Problem-Based Learning On Problem Solving. Gifted Child Quarterly, 36(4), 195-200.

Hernani, Mudzakir, A., \& Aisyah, dan S. (2015). Membelajarkan Konsep Sains Kimia Dari Perspektif Sosial Untuk Meningkatkan Literasi Sains Siswa Smp. 1028, 152.

Hmelo-Silver, C. E. (2014). Problem-Based Learning: What and How Do Students Learn? Educational Psychology Review, 16(3), 235-266.

Kirschner, P. A., Sweller, J., \& Clark, R. E. (2016). Why Minimal Guidance During Instruction Does Not Work: An Analysis of the Failure of Constructivist, Discovery, Problem-Based, Experiential, and Inquiry-Based Teaching. Educational Psychologist, 41(2), 75-86.

Kurniawan, A. (2016). Penerapan Model Pembelajaran Inkuiri Terbimbing Berbantuan Cmaptools dalam Pembelajaran Fisika untuk Meningkatkan Kemampuan Kognitif dan. Jurnal Penelitian Pendidikan, 1(1), 10-13.

MADINIAH, S. (2015). Model Guided Inquiry Berbasis Scientific Approach Terhadap Hasil Belajar Ipa Biologi Siswa Kelas Vii Smp Negeri 14 Yogyakarta .... Jurnal Pendidikan, 2(1), 20-29.

Minner, D. D., Levy, A. J., \& Century, J. (2016). Inquiry-based science instruction-what is it and does it matter? Results from a research synthesis years 1984 to 2002. Journal of Research in Science Teaching, 47(4), 474-496.

Novianti, M., \& Tjalla, A. (2013). Perilaku asertif pada remaja awal. Jurnal Universitas Gunadarma, 3(2), 43-60.

Novrizal, F. (2012). model pembelajaran sains teknologi masyarakat terhadap peningkatan penguasaan konsep fisika pada konsep usaha energi; penelitian kuasi eksperimen di SMP .... Jurnal Pendidikan, 1(3), $40-49$.

Purwanti, L. (2013). Peningkatan aktivitas pembelajaran IPA dengan media benda konkret pada siswa kelas II SDN 01 Kaling Tasikmadu Karanganyar tahun 2009/2010. Jurnal Pendidikan, 3(1), 13-21.

Sanjaya, W. (2012). Pembelajaran dalam implementasi Kurikulum Berbasis Kompetensi. Kencana.

Sanjaya, W. (2014). Strategi pembelajaran berorientasi standar proses pendidikan. Strategi Pembelajaran Berorientasi Standar Proses Pendidikan / Wina Sanjaya, 1(1), 1-99. https://doi.org/2011

Slameto. (2015). Belajar dan Faktor-faktor yang Mempengaruhinya. Jakarta: Renika Cipta.

Trianto. (2012). Model Pembelajaran Terpadu: Konsep, Strategi, dan Implementasi dalam Kurikulum Tingkat Satuan Pendidikan (KTSP). Jakarta: Bumi Aksara.

Wong, K. K. H., \& Day, J. R. (2014). A Comparative Study of Problem-Based and Lecture-Based Learning in Junior Secondary School Science. Research in Science Education, 39(5), 625-642. 